\title{
УКРАЇНСЬКО-РОСІЙСЬКІ ІНФОРМАЦІЙНІ ВІЙНИ: АСПЕКТИ, СЦЕНАРІЇ, КОМУНІКАТИВНІ СТРАТЕГІЇ
}

\author{
Людмила ПАВЛЮК
}

\author{
Львівський національний університет імені Івана Франка, \\ вул. Генерала Чупринки, 49, Львів, Украӥна, 79044, \\ tel. (0322)2394-181, \\ e-mail:pavlyukl@yahoo.com
}

\begin{abstract}
Висвітлено особливості тривання та лінгвістичні форми найбільш екстремних інформаційних кампаній, які демонструють різницю геостратегічних інтересів України та Росії.. Матеріал, впорядкований за хронологічним і тематичним принципом, відтворює зміст стратегій захисту незалежності у зв'язку із процесами політичногромадянської ідентифікації в Україні.

Ключові слова: інформаційна війна, інформаційний простір, політичні конфлікти, риторичні засоби, персуазивні стратегії, сценарій репрезентації подій, метафоричний сценарій, кібервійни, віртуальні сценарії, ідентичність.
\end{abstract}

Термін «українсько-російські інформаційні війни» є звичним, часто вживаним зворотом у мас-медійному дискурсі аналізу державотворних процесів. Українськоросійська конфронтація в інформаційному просторі розгортається на тлі конфлікту стратегічних інтересів держав: $з$ одного боку - прагнення української сторони зміцнити програму самостійного, поза полем гравітацій Росії, розвитку, а з іншого боку - намагання Росії утримати Україну в орбіті своїх впливів, поновити символічну потугу колишньої імперії через синхронізацію політичних стратегій на пострадянському просторі. Низка сенситивних залежностей - на зразок «газового», «кримського», «мовного» питань - робить Україну відкритою і вразливою для інформаційного пресингу з боку Росії.

Вислів «інформаційні війни» має напівметафоричний характер, адже війною у мас-медійному дискурсі може бути назване будь-яке зіткнення чи конфлікт інтересів. А з іншого боку, намагання політологів і комунікологів укладати цей вислів у виразно означені термінологічні рамки. Георгій Почепцов пише про інформаційні війни як вид дестабілізаційних технологій, суть яких полягає у «досягненні домінування на символічному полі, оскільки саме воно $€$ полем інтерпретації фактів» [22, с. 170]. Ареною боротьби в інформаційній війні стає масова свідомість, знаряддям - «комплекс заходів інформаційного впливу», а метою - «зміна поведінки людей та нав'язування їм цілей, що не входять до їх інтересів» [2].

Проміжною ланкою між концептами інформаційної війни як жорсткої, але риторичної за суттю техніки домінування, та війни у властивому сенсі мілітарних дій

(C) Павлюк Людмила, 2012 
став концепт кібервійни - інформаційних диверсійних операцій, спрямованих на виведення із ладу комп'ютерних інфраструктур супротивника, заволодіння базами даних чи блокування роботи національних інформаційних систем. Найвідоміші прецеденти кібервоєн початку двадцять першого століття - атаки російських хакерів проти державних і корпоративних мереж комп'ютерного зв'язку в Естонії 2007 році, конфліктним тлом для яких стали міждержавні непорозуміння із приводу переміщення меморіалу радянським воїнам; блокування комп'ютерних систем у Грузії перед початком російськогрузинської війни 2008 року; атаки корейських хакерів у 2009 році на веб-сторінки державних та бізнесових інституцій США - держказначейства, міністерства транспорту, Нью-Йоркської фондової біржі, Пентагону [39; 41$]$.

Кібервійни зазвичай належать до технічних стратегій, операційних аспектів загального інформаційного чи/і мілітарного протистояння між державами. Інформацію про корейських хакерів світові медіа подавали у модальності припущення, але ії важко було спростовувати на тлі офіційно поширюваних у Пхеньяні політичних заяв про наміри «стерти Сполучені Штати із лиця землі». Кібератаки, авторство яких приписували Росії, також мали виразно окреслений контекст експансивних геополітичних стратегій відновити економічне і політичне домінування Росії на колишніх радянських територіях, розширити інструментарій впливу на міжнародну політику пострадянських держав.

Інформаційні війни покладають на їх учасників набагато жорсткіші завдання, аніж, для порівняння, інформаційні кампанії. Головною імплікацією військового становища, нехай інформаційного, є право на агресію і безкомпромісна, безцеремонна настанова стосовно методів, які можуть бути як завгодно цинічними. У разі інформаційної війни ідеться про завдання реальної політичної, економічної, моральної шкоди супротивному таборові - тому це справдешня війна, боротьба на знищення, але поняття жертв і деморалізації супротивника не передбачає прямих фізичних втрат - тому це лише інформаційна війна.

У такому форматі лише інформаційної війни - напруженому, екстремному за періодичністю та інтенсивністю конфліктних спалахів, але все ж позначеному свідомопідсвідомим униканням стадії насильства - розвивалися українсько-російські стосунки упродовж епохи незалежності. Прикметно, що в українському мас-медійному дискурсі назви елементів сценарію війни, - такі як зброя, учасники війни, перемоги і поразки, вживають і у метафоричному, і у буквальному сенсі. Буквалізація образу війни і його елементів означує наближення конфлікту до екстремних меж - стадії військового конфлікту, збройних сутичок. Інформаційні війни епохи незалежності мали різний ступінь тяжіння до переходу пропагандистських, економічних, дипломатичних методів 3'ясування стосунків між державами до силових сценаріїв, демонстрації мілітарних намірів. Популярні медіа, зокрема преса із нахилом до сенсаційності, фіксували стани очікування фізичних силових дій із певним, а іноді суттєвим випередженням стосовно реальності. І у випадку із Тузлою у 2003 році, і у випадку газової війни 2006 року масмедіа включали у перелік прогнозів можливість військового розгортання конфлікту: «Сьогодні Украӥна вперше стоїть на порозі реального збройного конфлікту»[30]; «Як виграти у Росії? На жаль, експерти припускають перехід «газового» конфлікту у військове протистояння» (Експрес, 5-12.01.06). 
Інформаційна війна із приводу позиції України у зв'язку з військовими діями Росії на Кавказі перевершила за радикальністю бачень і, відповідно, емоційною напругою попередні епізоди політичного та інформаційного протистояння. Але попри драматичний пафос конфлікту-2008, і у цьому разі еволюційною функцією українсько-російських інформаційних протистоянь стало підтвердження статусу української незалежності і намагання надати завершеності інституційним основам і стратегічним доктринам держави.

Тематичні, інформачійні приводи українсько-російських віртуальних воєн протягом епохи незалежності, попри різницю форм і сценаріїв, позначені спільністю вектора внутрішніх сенсів - дистанціювання зовнішньополітичних стратегій та громадянських ідентичностей України і Росії. Основні предмети суперечок і причини оголошення інформаційних станів «військової готовності» у 2000-2009 роках: територіальна цілісність, кордони, претензії щодо територій; статус регіонів; посилення прозахідного курсу України, інтеграція у світові структури, зокрема плани стосовно вступу України до НАТО, статус Чорноморського флоту, вступ України до ЄС; історична спадщина, символіка, Голодомор; мовне питання в Україні.

Хронологію прещедентів і епізодів у літописі українсько-російських інформаційних воєн початку двадцять першого тисячоліття, на етапі спроб реалізувати доктрини євроатлантичної інтеграції і пов'язаного із цим вектором зовнішнього тиску та внутрішньої поляризації, репрезентують декілька основних, тісно пов'язаних між собою тематичних рубрик:

територіальні конфлікти, тема иілісності держави:

2003 - конфлікт навколо острова Тузла; громадянська і мас-медійна мобілізація

в Україні у відповідь на заяву глави адміністрації президента Росії А. Волошина про наміри Росії захищати претензії на Тузлу;

2006 - російська Держдума ухвалила рішення стосовно розгляду питання про можливу передачу Росії півострова Крим;

геостратегічні орієнтири:

2004 - інформаційно-психологічна кампанія дискредитації «прозахідного», «проамериканського» кандидата В. Ющенка та політиків національнодемократичного табору під час Помаранчевої революції;

2008 - інформаційне блокування політичних кроків України, спрямованих на вступ до Європейського Союзу [4];

2009 - коментарі В. Путіна із приводу «малоросійської землі - України»;

2009 - відкритий лист і відеозвернення Д. Медведєва до В. Ющенка, у якому російський

президент покладає провину за конфлікти між двома державами на українську сто-

рону і погрожує відтермінуванням приїзду російського посла до Києва; економічні непорозуміння:

2005 - «газова війна» проти України;

2009 - конфлікти із приводу поставок російського газу в Україну; негативна реакція Москви на угоду України із Свросоюзом про модернізацію української газотранспортної інфраструктури; 
статус Чорноморського флоту Росії в Украӥні:

2006 - «війна заяв» і загострення стосунків у зв'язку із переговорами про ста-

тус Чорноморського флоту; конфлікти із приводу інвентаризації об’єктів ЧФ

Росії у Криму та права власності на маяки [11];

2008 - конфлікти, спричинені участю військових кораблів ЧФ Росії у військових діях проти Грузіі;

вступ Украӥни до НАТО, вибір військових стратегій:

2006 - «десанти» російських політиків і громадських активістів у Криму під час

антинатовських протестів на півострові;

2008 - заяви МЗС Росії про намір вжити «усіх заходів», щоб не допустити всту-

пу в Альянс України [24].

Окрему хронологічну лінію складають інформаційні сюжети, які стосуються етнічно-мовних конфліктів, проблеми «захисту прав російськомовного населення». Увага до культурного компонента міждержавних стосунків ніколи не згасала, адже тема культурно-мовної близькості найважливішим обгрунтуванням російської інформаційної присутності в Україні. У 2008 році актуальність цієї теми у черговий раз поновив коментар департаменту інформації російського зовнішньополітичного відомства: «до питання про російську мову в Україні треба підходити із врахуванням законних прав та інтересів мільйонів громадян України, які вважають їі своєю рідною чи використовують у повсякденному житті» [17].

Хронологія тривання українсько-російських інформаційних «військових дій» тісно пов'язана з активізацією внутрішньої підтримки позицій Росії з боку проросійських організацій, ліворадикальних партій та інших не достатньо інтегрованих у субстрат української «політичної нації» та «громадянського суспільства» ідеологічних інгредієнтів. Протести, які періодично ініціюють маргінальні для загальноукраїнських масштабів, але впливові за локальними мірками сили, покликані демонструвати обгрунтованість заявок Росії на корекцію українських геополітичних стратегій:

2006, 2007, 2008 - КПУ, ПСПУ і «Російський блок» проводять акції для зриву навчань «Сі-Бриз» [14];

серпень 2008 року - депутати міського зібрання Севастополя заявляли про готовність мешканців міста у будь-який спосіб, включно із організацією живих щитів, перешкоджати можливій блокаді російських кораблів з боку ВМФ України [5].

Про інформаційні війни можна говорити як про активний дискурсивний супровід реальних конфліктів, який охоплює елементи артикуляції претензій, формулювання ідентифікаційних визначень, виголошення цілей і пропозицію практичних розв'язок конфлікту. Однак використання маніпулятивних лінгвістичних ресурсів може бути і відносно автономним, коли «наступальні» чи «оборонні» операції розгортаються переважно чи виключно у віртуальному просторі.

Існують як стратегії віртуалізації, інтенсифікації проблеми через маніпулювання символами, нагромадження екстремних визначень, так і протилежна риторична практика зниження статусу проблеми у громадській думці до рівня віртуальності. Масштаб 
об'єкта, який оголошено віртуальним, а отож позбавленим вартісності і перспективи, не має значення - це може бути явище (Помаранчева революція - це «не-подія», «подіянонсенс» («non-event»)) чи країна («Україна - не держава» (В. Путін) [28], «Грузія віртуальний проект США» (С. Лавров) [26]).

Незалежно від міри переважання «реальних» чи симульованих приводів і колізій в інформаційних війнах, ці символічні події надзвичайно значущі для шліфування аспектів ідентичності й формування громадянських проектів. Вперше це продемонструвала Тузла. Реальний фізичний привід цього конфлікту був мізерним, практичний вислід - практично нульовим, але масштаб текстогенного емоційного спалаху, спровокованого протистоянням, свідчив про особливу вагу теми кордонів для етноідентифікаційних процесів. Характерно, що російська сторона тяжіла до надміру стриманого висвітлення проблем Тузли - переважно у фреймі ділової господарської операції: «Тут насипають чотирьохкілометрову дамбу, яка возз'єднає острів із Росією». Мовляв, «як добре, що відновлюється коса, і зовсім незрозуміло, що там не подобається українцям» [29].

Із української перспективи Тузла виринула і як символ вразливості української сторони стосовно російських вимог, і як вираз готовності України протистояти цим вимогам. Шалені пристрасті у мас-медіа, пов'язані із конфліктом довкола острова Тузла, фактично сформували модель реакції українського суспільства на територіальну загрозу. Гііперемотивні форми реагування привернули увагу до потреби нормативного врегулювання конфлікту. В інституційно-правовому сенсі суперечки із приводу Тузли стосувалися насамперед практичної проблеми невирішеного статусу Керченської протоки, а ширше - потреби делімітації і демаркації українсько-російських кордонів.

Інформаційна війна із приводу позиції України у зв'язку з військовими діями Росії на Кавказі за напруженістю та серйозністю перевершила стратегічні імплікації попередніх протистоянь. Конфлікт «підважив» не одну проблему, а цілий їх комплекс. Загальна стратегічна парадигма заторкнутих у 2008 році питань - структуризація пострадянського простору із врахуванням євроатлантичних інтересів України, глобальна ідентифікація пострадянських держав. Події у Грузії стали приводом для трансляції простого, але змістовного меседжу: «Україна існує і має свої інтереси», «Україна має право на власне бачення». Критика позицій В. Ющенка у ході російсько-грузинського конфлікту була пов'язана із неприйняттям його безкомпромісності, категоричності в оцінках позицій Росії, а підтримка - із розумінням його логіки прямоти і визначеності стосовно українських стратегічних цілей: «Ющенко сподівався, що своїм підкреслено гострим осудом Москви він поліпшить шанси своєї країни на вступ до СС і НАТО» [9].

У 2009 році фактуальне поле російсько-українських інформаційних воєн підживлювали і економічні конфлікти, і колізії ідентифікаційно-ідеологічного плану. Широкого розголосу в українській і світовій пресі набули висловлювання В. Путіна стосовно ексклюзивного права Росії визначати стосунки із «малою Росією». Не тільки ідеї традиційного дискурсу імперських ідеологем, а й лексика «забутих газет» видалися прем'єрові придатними для формулювання засад російської політики щодо України. Про амбіції Росії як монополіста на визначення курсу російсько-українських відносин В. Путін говорить із посиланням на щоденники Денікіна, під час відвідин цвинтаря 
Донського монастиря, де похований Денікін: «Там у нього є міркування про велику та малу Росію, Україну. Він каже, щъо нікому не повинно бути дозволено втручатися у відносини між нами, це завжди було справою самої Росії» [23].

Концептуально-мовний репертуар інформаційних воєн в українсько-російських конфліктах 2000-2009 років грунтується на принципові концентрації емотивних елементів та максимальних контрастах позицій:

а) Активізація елементів образу війни: 1) на рівні метафоричному («нова газова атака Кремля»); 2) у модусі гіпотез, припущень, моделей: «А якщо завтра - війна?» [15]; «Раз плюнути! Ракетні війська Росії можуть знищити інфраструктуру всіх обласних иентрів Украӥни за одну добу» [13]; 3) у модусі передбачень чи реальних очікувань: «Україну попереджають про можливість повторення грузинського сиенарію»[31]; «Американський дипломат: «Росія напала на Грузію - наступною буде Украӥна»[1]. Засоби масової інформації зазвичай посилюють прогностичні модуси, і звичка згущувати фарби при коментуванні рівня загроз зростає пропорційно до сенсаціоналістського спрямування медіа, але, з іншого боку, суспільство має бути вдячним своїй публічній сфері за пильність у моніторингу безпеки і репрезентацію широкого спектру поглядів, включно із найбільш екстремними;

б) Концептуалізація військового Ми-Вони становища на глобальних рівнях. У час розгортання «газового конфлікту» 2006 року, Юрій Оробець, член паливно-енергетичного комітету парламенту, коментував економічні протистояння як вираз набагато більш глобальних рівнів протиборства: «Це геополітичний конфлікт між Україною і Росією та початок нового стратегічного наступу Російської імперії на цілу Європу. (...) Ширший результат: всі європейці мають усвідомити свою залежність від російських енергоносіїв, відчути свою уразливість до волюнтаристських заходів Москви...»[6];

в) Виписування Вони-образу на основі пейоративних ідеологічних кліше: «імперська політика Москви», «намагання повернути Україну в статус керованої через посередників васальної території Кремля», «волюнтаризм російських політиків», «імперіалістична політика колишньої союзної домінанти»;

в) Ланцюгова реакція перегляду договорів та відповідні дискурси історичних порахунків. Коли у 2006 році віце-прем'єр міністр та міністр оборони Росії С. Іванов заявив, що Росія може переглянути договір 1954 року, згідно із яким Україна за рішенням Микити Хрущова отримала Крим, тема одержала «симетричний» екстремний розворот в українських медіа: «Зрештою, якщо ставитися до цього серйозно, то чому переглядати саме умови 1954 року, а не таємний пакт Молотова-Рібентропа, який фактично визначив територіальні межі сучасної Європи, один із поділів Речі Посполитої чи, наприклад, вдатися в історію ще глибше та не переглянути давні межі Київської Русі? Звучить цілком абсурдно? Однак події останніх днів засвідчили, що часом зовсім абсурдні слова з Кремля можна почути на рівні серйозних заяв...» [7]. 
г) Стратегії інформаційного протистояння на рівні дискредитації чужих $i$ захисту власних символів репрезентовані багатьма емоційними, красномовними епізодами. У лютому 2006 року представники молодіжних організацій на Кримському півострові встановили українські прапори на маяках, які на той час уже було оголошено власністю України. У відповідь російські морські піхотинці, які перебували на кримському маяку «Херсонеський,» зірвали і пошматували український прапор [25]; липень 2008 року - акти вандалізму у Севастополі: представники проросійських організацій зірвали і скинули в море меморіальну дошку, встановлену на честь 90-річчя підняття українського прапора на кораблях Чорноморського флоту (подія сталася в часи УНР);

д) Громадянські акції і спонтанні вияви публічної мобілізації: у 2006 році політично свідомі громадяни висловлювали свою позицію, розсилаючи есемески «Пам'ятай про Тузлу, газ, терор НКВС...»; «Пора» проводила пікети «Не купуй російських товарів!» та ініціювала акцію «Маякни Путіну».

У серпні 2008 року громадянська мобілізація, пропорційно до зрослої політичної напруги конфлікту, набула яскраво виражених мілітарних тонів і почала переходити з інформаційної у практичну стадію, засвідчивши небезпечну межу, до якої у цей час наблизилось російсько-українське протистояння. Демонстрацію готовності до фізичної особистої участі у конфлікті виявили проросійські організації на півдні - рада отаманів Криму оголосила про збір добровольців для допомоги Північній Осетії [27]; українські праворадикали прореагували «симетрично», заявляючи про готовність, у разі потреби, оголосити набір волонтерів для підтримки Грузії у боротьбі за територіальну цілісність [20].

Українсько-російські інформаційні кампанії парадоксальним чином підсилювали і ефекти поляризації, і процеси консолідації сходу і заходу та груп еліт в Україні. Паралельно до поляризаційних процесів і на противагу їм, інформаційні війни 3 Росією підвищували рівень внутрішньої єдності суспільства, сприяють примиренню на лінії громадянської війни ідентифікацій. Вперше цей феномен стирання, ослаблення дихотомії «сходу-заходу» у ситуації зовнішніх загроз із подивом зауважили газетярі під час конфлікту навколо Тузли: «І в комуністів, і в донеччан миттєво прокинулася національна свідомість» [30]. Підставою для таких висновків, можливо надміру оптимістичних, стали коментарі тих російськомовних «східняків», які завзято полемізували із великодержавно-шовіністично налаштованими опонентами на форумах російських газет при обговоренні статей про Тузлу.

І рівень інтернетизації, і рівень емоційної заангажованості українців під час російсько-грузинської війни 2008 року виявився на порядок вищим, аніж у 2003 році, і численні «національно свідомі» представники російськомовного сектора українського громадянства радикально дистанціювали себе від проросійських інтерпретацій та ідентифікацій: «Регулярна армія Росії перебуває на території чужої країни $і$ бомбардує ї̈ міста. Які ще можуть бути сумніви з приводу того, хто не має рації [кто не прав]?»; «Мені, росіянину [русскому], який мешкає в Украӥні, дуже не хочеться, щоб мене захи- 
щзали Росіяни [Россияне]. Украӥна-моя краӥна. Я в нійживу і почуваю себе комфортно. Дякую, дорогі росіяни. Не треба!» [3].

Інтернет-комунікація у дедалі ширших масштабах стає полем битви політичних позицій, і ця тенденція, властива українсько-російським інформаційним війнам, збігається із вектором ідеологічної трансформації на глобальному рівні. Оглядач мережевих процесів Є. Морозов описує баталії у віртуальному просторі, пов'язані із захистом індивідуальних уявлень про національну гідність та геополітичну ідентичність, у термінах «цифрового націоналізму». Згідно із його інтерпретацією, для російського інтернет-воїнства коментарі із приводу російсько-грузинської війни перетворилися на інформаційну війну із західними медіа загалом [16].

Із якими результатами виходила Україна із кожної ситуації інформаційного протистояння, вирішення конфліктних питань у режимі ідеологічної безкомпромісності? У підсумкових коментарях стосовно найважливіших епізодів інформаційних воєн між Україною і Росією - Тузли-2003, газової війни 2005-2006 року, підтримки Грузії-2008, - українські медіа говорили про поразку української сторони.

Суперечливі оцінки результатів газового конфлікту 2009 року певною мірою віддзеркалили об'єктивну складність ситуації, у якій перемогою можна було назвати осягнення відносних переваг і саму лише відсутність явної поразки. Іще більшою мірою оцінні різночитання угоди продемонстрували роз'єднаність української еліти у ставленні до стратегічного питання енергетичної безпеки. Отож діапазон оприлюднених думок про позитиви і негативи насідків російсько-українського протистояння 2009 року надзвичайно широкий: від «Ми знову програли Росії в інформаційній війні» [19]; «Домовленості Тимошенко і Путіна означають капітуляиію Києва?» [8] - до «Західні експерти кажуть, щзо Україна перемогла у газовій війні» [10]. Тижневик «Дзеркало тижня» вдався до природної у такій ситуації тактики стримано-диференційованих оцінок: «Угода - иее ніяка не перемога України і не перемога Росії»; «Компроміс. I життя після нього» [18].

Отож, медіа фіксували наслідки російсько-українських інформаційних воєн у термінах втрачених, не здобутих чи не надто виразних перемог. Та все ж спалахи емоцій, які супроводжували конфліктні стани, та величезні масиви інформації, сформовані енергією протистоянь, мали важливий еволюційний структуротворчий сенс. Події українсько-російських інформаційних воєн набувають особливої значущості у контексті процесів увиразнення ідентичності, узгодження ідеальних стратегічних проектів із реальними політичними кроками. На рівні держави тривав структурно-інституційний розвиток, а на рівні суспільства - зростало відчуття особистої психологічної причетності громадян до проекту «Україна». Навіть якщо інформаційна і фактична позиція України була далекою від тріумфальної, сам процес тривання конфліктів - на противагу їх униканню будь-яким коштом - виконував позитивні функції стримування та противаг. Інформаційні війни перманентно демонстрували готовність української сторони до опору $i$ висловлення незалежної позиції, сприяли опануванню логіки реальної паритетності. Психологічна рівність в українсько-російських стосунках фундаментально порушена, і полягає це у тому, що явищам рівноцінним, рівнозначущим за природою 
надають різної ваги. До прикладу, український родовід російського громадянина - це його глибоко приватна скромна справа, натомість російські корені та ідентичність українського громадянина - це глобальна, надзвичайної політичної ваги проблема, вмонтована у мотивації російської присутності і російських інтересів в Україні.

Однією із ініціатив у справі встановлення симетрії психологічних позицій сторін у російсько-українських контактах була пропозиція Міністерства закордонних справ України провести спільний із російськими колегами моніторинг дотримання прав українців у Росії та росіян в Україні. Коментуючи відмову російської сторони проводити моніторинг та порушувати проблему політичної репрезентованості українців у Росії, член правління УНП С. Хмара формулював радикальну ідею піднесення статусу 20 мільйонів українців у 146-мільйонній Росії: «Якби українці в Росії мали такі самі права, як і росіяни в Украӥні, другою державною мовою в Російській Федерації була б українська» [32].

Російські керівники не минали нагоди дати Україні відчути свою позицію об'єкта маніпуляцій (на противагу суб'єктові політики), чию долю вирішують залаштунково. На зустрічі Ради Росія-НАТО 4 квітня 2008 року В. Путін у розмові із Джорджем Бушем неофіційно, але однозначно дав зрозуміти, що у разі вступу до НАТО Україна може втратити цілісність [28]. Сенс інформаційних воєн для України у такій ситуації - сигналізувати світові і народові про первинність власних інтересів. Війни у такій ситуації просто не могло не бути. Але вона залишалася війною позищій.

Гострі протистояння в інформаційному просторі $є$ природним комунікативним тлом і супроводом процесів «цивілізованого розлучення». Кожен етап дистанціювання членів колишньої родини - поділ спільного майна (кордони і ЧФ), доля «спільних дітей» (статус меншин), а особливо перспективи майбутніх геостратегічних союзів

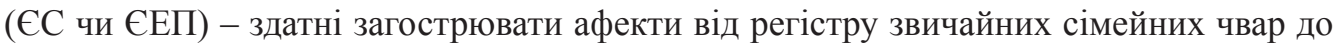
емоцій «холодної війни». Відносна цивілізованість і відносні функціональні позитиви формату інформаційних війн полягали у тому, що, якими би брутальними не виглядали окремі епізоди пропагандистських атак, методи чорного піару та інформаційні диверсії у «тилу» супротивника, все ж інформаційні війни фактично слугують психологічним механізмом каналізації екстрем і у своєрідний спосіб стримують використання набагато менш цивілізованих форм протистояння - справжньої війни, фізичного насильства.

Моральною «територією», яку захищала Україна у ході інформаційних протистоянь із Росією, була гідність держави і ії право на самостійний вибір стратегій розвитку. На зовнішні спроби образити і обмежити свободу самоідентифікацій суспільство відповідало високими рівнями конфронтативності національного дискурсу. Втім, попри екстремні емоційні форми інформаційних стосунків між Україною і Росією, завжди існувала перспектива примирення і орієнтація на медіативні розв'язки добре визрілих конфліктів, які зав'язувалися протягом десятиліть і століть нерівноправного співіснування i, відповідно, асиметричної комунікації. Акумульований конфронтативний досвід зумовлював і потребу у своїй протилежності - кооперативних формах міждержавного спілкування. 


\section{СПИСОК ВИКОРИСТАНОЇ ЛІТЕРАТУРИ}

1. Американский дипломат: «Россия напала на Грузию - следующей будет Украина» [Електронний ресурс]. - Режим доступу : http:/censor.net.ua/go/offer-ResourceID--92122

2. Березовець T. Інформаційні війни в політиці [Електронний ресурс] / Т. Березовець. Режим доступу : http://www.polittech.org/index. php?option=com_content\&task=view\&i $\mathrm{d}=455 \&$ Itemid $=36$

3. В России уже заявили о готовности защищать «своих граждан» в Крыму [Електронний ресурс]. - Режим доступу : http:// ru.proua.com/news/2008/08/28/160521.html

4. Величенко $C$. Російська інформаційна війна проти перспективи членства України в ЄУ [Електронний ресурс]. / С. Величенко. - Режим доступу : http://www.zgroup.com. ua/article.php?articleid $=837$

5. Вооруженные силы РФ будут уничтожать все цели на море и воздухе близ побережья Абхазии [Електронний ресурс]. - Режим доступу : http://korrespondent.net/ russia/550530

6. Ганус А. Як виграти у Росії? / А. Ганус, О. Стецишин // Експрес. -2006. - 5-12 січня.

7. Джміль Д. Росія погрожує забрати Крим / Д. Джміль // Поступ. - 2006. - 5-11 січня.

8. Договоренности Тимошенко и Путина означают капитуляцию Киева? [Електронний peсурс]. - Режим доступу : http://www. unian.net/rus/news/news-295724.html

9. Европейские СМИ: Россия подпитывает политический кризис в Украине [Електронний ресурс]. - Режим доступу : http:// korrespondent.net/ukraine/politics/579018

10. Західні експерти і політики кажуть, що Україна перемогла у газовій війні [Електронний ресурс]. - Режим доступу : http: //ua/ story/174886/ad68c/4756

11. Касьяненко М. Маяки конфліктів / М. Касьяненко // День. - 2006. - 17 січня

12. Київ обурений заявами консула РФ у Харкові [Електронний ресурс]. - Режим доступу : http://www.newsru.ua/arch/ ukraine/02feb2009/genkonsool.html

13. Коваленко I. Раз плюнути! Ракетні війська Росії можуть знищити інфраструктуру всіх обласних центрів України за одну добу. / І. Коваленко, О. Кущій // Експрес. - 2008. 14-21 серпня.

14. КПУ, ПСПУ і «Руський блок» зірвали головну частину навчань «Сі-Бриз» [Електронний ресурс]. - Режим доступу : http://5. ua/newsline/232/0/52407/

15. Кущій О. А якщо завтра - війна? / О. Кущій // Експрес. - 2008. - 14-28 серпня.

16. Morozov E. Russia/ Georgia: War of the Web. [Електронний ресурс] / E. Morozov. - Режим доступу : http://www.opendemocracy.net/russia/ article/russia-georgia-war-of-the-web

17. Москва назвала «форсированную украинизацию» нарушением прав граждан [Електронний ресурс]. - Режим доступу : http:// news.bigmir.net/article/ukraine/35805/

18. Мостова Ю. Компроміс. І життя після нього / Ю. Мостова // Дзеркало тижня. - 2009. -24-30 січня.

19. Мы снова проиграли России в информационной войне [Електронний ресурс]. - Peжим доступу : http://unian.net/rus/news/ news-293481.html

20. Позиція Луганської організації ВО «Свобода» щодо втручання Російської Федерації у грузино-осетинський конфлікт [Електронний ресурс]. - Режим доступу : http:// narodna.pravda.com.ua/politics/489c20e405ea6/

21. Почепцов Г. Информационные войны / Г. Почепцов. - Рефл-бук, 2001.

22. Почепциов Г. Информация \& дезинформация / Г. Почепцов. - К., 2001.

23. Путін вичитав, що Росія сама розбереться з Малоросією. [Електронний ресурс]. - Режим доступу : http://www.pravda.com.ua/ news/2009/5/24/95281.htm 
24. Расширение НАTO за счет Украины и Грузии вынудит Москву принять меры военного характера [Електронний ресурс]. - Режим доступу : http://news.bigmir.net/article/ world/28033/

25. Росіяни пошматували український прапор! // Експрес. - 2006. - 16-23.

26. РФ назвала Грузию виртуальным проектом США. [Електронний ресурс]. - Режим доступу : http://www.utro.ua/ news/2008/08/13/93547.shtml

27. Совет атаманов Крыма объявил сбор добровольцев для помощи Южной Осетии [Електронний ресурс]. - Режим доступу : http:// www.unews.com.ua/index.php?option=com content\&task $=$ view\&id $=94987 \&$ Itemid $=19$

28. Тимошенко ответила на слова Путина о том, что «Украина - не государство» [Електронний ресурс]. - Режим доступу : http:// pravda.com.ua/ru/news/2008/4/9/74299.htm

29. Тишкун Ю. Затишшя перед бурею: російські медіа про конфлікт у Керченській протоці / В. Поліщук. Ю. Тишкун //. Поступ. - 2003. - 23-29 жовтня.

30. Тишкун Ю., Полішук В. Тузла: останні метри миру / В. Поліщук. Ю. Тишкун //. Поступ. - 2003. - 23-29 жовтня.

31. Україну попереджають про можливість повторення грузинського сценарію [Електронний ресурс]. - Режим доступу : http:// www.pravda.com.ua/news/2008/8/11/79789.htm

32. Українці вимагають, щоб другою державною мовою Російської Федерації була українська [Електронний ресурс]. - Режим доступу : http://booknews.cv.ua/index. php?newsid $=9469$

33. Ђ: Рада раскололась об Россию [Електронний ресурс]. - Режим доступу : http:// korrespondent.net/worldabus/573334

34. Bednarek M. Evaluation in Media Discourse: Analysis of a Newspaper Corpus / M. Bednarek. - London, New York : Continuum, 2006.

35. Ellis D. Transforming Conflict: Communication and Ethnopolitical Conflict / D. Ellis Lanham : Rowman \& Littlefield, 2006.

36. Political Discourse in the Media: Cross-Cultural Perspectives. / A. Fetzer, G. E. Lauerbach, eds. - Amsterdam; Philadelphia : J. Benjamins Pub. Co., 2007.

37. Inkinen S. ed .Mediapolis: Aspects of Texts, Hypertexts, and Multimedial Communication / S. Inkinen. - Berlin, New York : W. de Gruyter, 1999.

38. Jordan T. Hactivism and Cyberwars: Rebels with a Cause? / T. Jordan, P. Taylor. - Taylor \& Francis, Inc., 2005.

39. North Korean Cyber Attacks? [Електронний pecypc]. - Режим доступу : http://www. foxbusiness.com/searchresults/m/24718991/ north-korean-cyber-attacks.htm

40. Raboy M. eds. Media, Crisis and Democracy: Mass Communication and the Disruption of Social Order / M. Raboy, B..Dagenais. - London, Newbury Park, New Delhi : Sage Publications, 1992.

41. Some recent Cyber Attacks [Електронний pecypc]. - Режим доступу : http://www. washingtonpost.com/wp-dyn/content/ article/2009/07/08/AR2009070801981.html

42. The Discursive Construction of National Identity / [Wodak R., de Cillia R., Reisigl M., Liebhart K.]. - Edinburg Un-ty Press, 1998. 


\title{
UKRAINIAN-RUSSIAN INFORMATION WARS: AFFECTS, SCENARIOS, AND COMMUNICATION STRATEGIES
}

\section{Lyudmyla PAVLYUK}

\author{
Ivan Franko National University of Lviv, \\ 49, Chuprynky Str., Lviv, Ukraine, 79044, \\ tel. (0322)2394-181, \\ e-mail:pavlyukl@yahoo.com
}

The article examines particularities of duration and linguistic forms of the most extreme information campaigns that demonstrate differing strategic interests of Ukraine and Russia. The factual material, arranged in accordance with chronological and thematic principle, represents strategies of protecting independence in relation with processes of public and political identification in Ukraine.

Key words: information war, information space, political conflicts, rhetorical means, persuasive strategies, scenario of representation, metaphorical scenario, cyber war, virtual scenario, identity.

\section{УКРАИНСКО-РОССИЙСКИЕ ИНФОРМАЦИОННЫЕ ВОЙНЫ: АФФЕКТЫ, СЦЕНАРИИ, КОММУНИКАЦИОННЫЕ СТРАТЕГИИ}

\author{
Людмила ПАВЛЮК \\ Львовский национальный университет имени Івана Франко, \\ ул. Генерала Чупринки, 49, Львов, Украина, 79044, \\ тел. (0322)2394-181, \\ e-mail:pavlyukl@yahoo.com
}

\begin{abstract}
В статье отражены особенности протекания и лингвистические формы наиболее экстремных информационных кампаний, которые демонстрируют разницу геостратегических интересов Украины и России. Материал, упорядоченный по хронологическому и тематическому принципу, воспроизводит содержание стратегий защиты независимости и процессов политической и гражданской идентификации на Украине.

Ключевые слова: информационная война, информационное пространство, политические конфликты, риторические средства, персуазивные стратегии, сценарий репрезентации событий, сценарий войны, кибервойна, виртуальные сценарии, идентичность.
\end{abstract}

